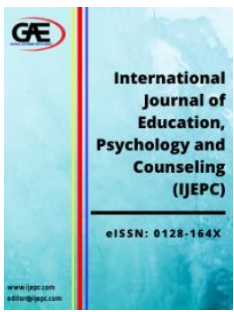

\author{
INTERNATIONAL JOURNAL OF \\ EDUCATION, PSYCHOLOGY \\ AND COUNSELLING \\ (IJEPC) \\ www.ijepc.com
}

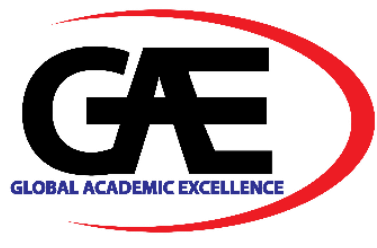

\title{
VALIDITY AND RELIABILITY OF REBT MODULE CREATIVE GUIDANCE ON IRRATIONAL THINKING, AGGRESSIVE BEHAVIOR, AND SELF-ESTEEM
}

\author{
Ibrahim Abd Ghani ${ }^{1 *}$, Norsayyadatina Che Rozubi ${ }^{2}$ \\ 1 Universiti Pendidikan Sultan Idris, Malaysia \\ Email: ibrahimabdghani521@gmail.com \\ 2 Universiti Pendidikan Sultan Idris, Malaysia \\ Email: norsayyadatina@fpm.upsi.edu.my \\ Corresponding Author
}

\section{Article Info:}

\section{Article history:}

Received date:04.10.2020

Revised date: 10.11 .2020

Accepted date: 25.11 .2020

Published date: 08.12.2020

To cite this document:

Abd Ghani, I., \& Che Rozubi, N. (2020). Validity And Reliability Of REBT Module Creative Guidance On Irrational Thinking, Aggressive Behavior And Self-Esteem. International Journal of Education, Psychology and Counseling, 5 (37), 283-296.

\section{DOI: $10.35631 /$ IJEPC.5370023.}

This work is licensed under CC BY 4.0

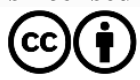

Abstract:

Rational Emotive Behavioural Therapy (REBT) Module - Creative Guidance is designed to prevent irrational thoughts, lower aggressive behavior, and increase self-esteem. This module contains seven sub-modules based on behavioral approaches based on the theory of Rational Emotive Behavior Therapy (REBT) by Albert Ellis (1955) and integrated with creative Guidance. It combines elements of Music, technology, and play. To measure the validity of the content, the certification method by five experts was used while 40 primary school students aged 11 years were selected to follow the guidance program using this module. It is run for two weeks in a row. The findings of the study show that the REBT-Creative Guidance Module has a content validity index value of $80 \%$., The cost of Cronbach's Alpha coefficient of Creative REBT-Guidance Module is high at .978. Reliability with an amount.930 In conclusion, new contributions to guidance and counseling teachers in Malaysia. It is also suitable for use in a local context focused on primary school students. Counselors can also use this module, Teachers or facilitators as one of the alternative interventions for primary school students throughout Malaysia, especially on the Development and Development of Student Personality, Improving Student Discipline, Improving Student Careers and Psychosocial and Mental Well-Being.

Keywords:

Validity, Reliability, REBT Module-Creative Guidance 


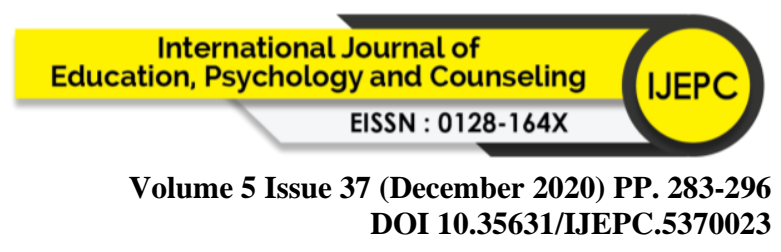

\section{Introduction}

A holistic educational approach needs to be applied to apply knowledge, values, and skills in pedagogy, cognitive, affective, and psychomotor aspects. Through Education Aspirations 2018-2023, - The Balance of the head, hand, and heart of the Ministry of Education Malaysia (MOE). Through these aspirations, 3M emphasizes, that is, Human, humanizing students and Shaping personality through the education system as a whole. It focuses on Humanizing Students, Shaping Personality, as Contained and Educational Aspirations 2018-2023.

The need for valuable relationships in schools is significant in producing a high moral generation. Lately, it has often been saying about the aspect of becoming a student. Through the Engineering of Counseling and Counseling Services, which outlines some elements that need to be considered in the implementation of services towards that. Among them is Student Personality Development and Development, Improving Student Discipline, Improving Student Careers, and Psychosocial and Mental Well-Being of Students.

Thus, a module using a guidance and counseling approach was developed to address the issue of self-development known as the REBT-Creative Guidance Module. It's because according to Azrinawati et al. (2013), some essential factors on achievement are demographic aspects, motivation, and learning strategies. The cause is a characteristic of students that dominates internal factors.

They are taking into account the noble intentions of the Ministry of Education Malaysia (MOE) on the role and function of Guidance and Counseling teachers themselves in helping relationships. The need especially for search, exploration of new interventions in assisting relationships in requirements to be adapted to the current situation. It's because conventional methods of oral intervention are said to have less impact on solving disciplinary problems in terms of student behavior.

Theoretical aspects, seen through the theoretical approach of Rational Emotive Behavioral Therapy (REBT) In addition to adults, children also face issues and irrational thinking. Elbert Ellis pioneered Rational Emotive Behavioral Therapy (REBT) for children and adolescents in the mid-1950s. The diversity of helping relationships is also seen from a creative aspect. Through new approaches such as creative Guidance, an adaptation of musical elements, and the use of technology. Various Techniques in this helping relationship and embroidered with the right and appropriate theory can help make guidance services in schools, exceptionally primary schools more flexible and achieve objectives.

The REBT-Creative Guidance Module is based on the Rational Emotional Behavior (REBT) approach introduced by Albert Ellis in 1955. This approach emphasizes that an individual's cognitive aspects influence emotional and behavioral factors as well as interrelated (Ellis, Shaughnessy \& Mahan, 2003; Wallen, DiGiuseppe \& Dryden, 1992). While Alternative Guidance, especially Creative Guidance is very necessary, where Guidance and Counseling teachers in Malaysia who face a variety of client backgrounds, explore various methods and do not rely only on conventionally that is just talking, (Azizah 2015). Guidance services, especially for primary schools, especially those involving Alternative Guidance such as Art Therapy, Creative Guidance, Play Therapy, are considered something new. It needs to be 


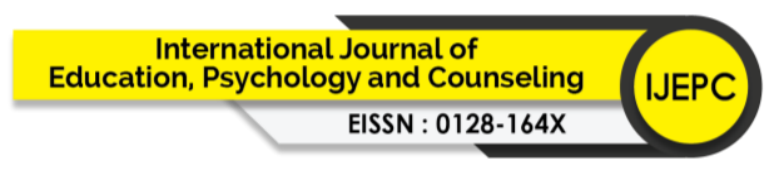

Volume 5 Issue 37 (December 2020) PP. 283-296

DOI 10.35631/IJEPC.5370023

further developed by conducting other studies that have not yet been explored (Norsayyiditina, 2017).

Creative Guidance in Malaysia is one of the alternative mediums for Guidance and Counseling, especially in primary schools. It is through this medium that will be applied in the implementation of the study in dealing with disciplinary issues. Part of the Creative Guidance element is Music. David Adward (2004)

According to Cathy. A Malchiodi, (2005), also describes music therapy as part of Creative Therapy, where the effect is very complimentary, especially, in changing behavior, psychology, and ability to socialize. What is interesting here is adapting music therapy as a medium of Guidance. Looking at it psychosocially, it connects my behavior in mixing, in emotions it helps to stabilize emotions, as well as in communication, it helps to build relationships. For the cognitive, as a means of communication, and emotionally, for a sense of security, (David Adward, 2004). Music therapy is something magical that is widespread, something that is natural, flexible all accustomed to Music, and it is an option. The Music consists of, singing, listening, playing, and movement (Deb Del Signore, Rebecca Froman, Erica Hornthal, 2012).

With the effort to integrate the concept of REBT with Creative Guidance, it can produce skill in solving problems comprehensively from various aspects of behavior, emotional and spiritual. REB Guidance Module

\section{Research Objective}

This study was conducted to:

(i) Measure the validity value of the content of the REBT Guidance Module-

Creative Guidance.

(ii) Measure the reliability value of the REBT Module-

Creative Guidance.

(iii). Testing the Validity and Readability of the REBT -Creative Guidance module for children.

\section{Literature Highlights}

The use of Rational Emotive Behavioral Therapy (REBT) theory ends in helping to solve various social problems related to behavior. Especially involving children. (Bernard, 2006). However, continuous improvement must be implemented by combining creative elements so that REBT is in line with the needs of primary school students in Malaysia, especially in this era of technological development. In line with the view that to be successful, REBT clan specialists need to take into account different cultures, different clients, and various types of a person's problems (Criddle, 2007).

Although REBT emphasizes the emotional, thought, and behavioral aspects, but REBT only focuses on the element of thinking that is the belief system "belief system" (irrational thinking to rational thinking). In this theory, the focus is on rationalizing irrational thinking. It assumes that correcting belief systems alone is enough to produce good behavior. According to Mohammad Nasir (2006), REBT theory develops through various approaches to cognitive behavioral therapy. To this day, REBT has become one of the most popular therapeutic approaches because it has a positive impact on clients and saves costs and time. Cognitive- 


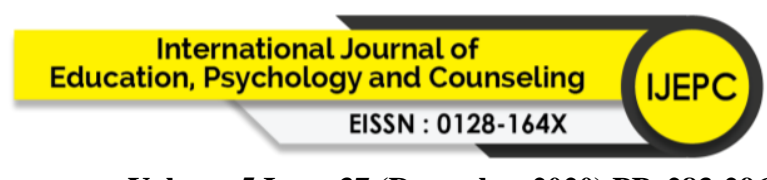

Volume 5 Issue 37 (December 2020) PP. 283-296

DOI 10.35631/IJEPC.5370023

behavioral therapy is derived from learning theory based on the techniques and procedures used. Thus, there is no specific theory underlying the practice of new behavior therapy (Corey, 2004). Behavioral therapy is a clinical orientation practice based on experimental approaches in studying behavior (Abdul Malik, 2004).

Alternative Guidance, especially Creative Guidance is essential, where Guidance and Counseling teachers in Malaysia who face a variety of client backgrounds, explore various methods and do not rely only on conventionally that is just talking, (Azizah 2015). Guidance services, especially for primary schools, especially those involving Alternative Guidance such as Art Therapy, Creative Guidance, Play Therapy, are considered something new. It needs to be further developed by conducting other studies that have not yet been explored (Norsayyiditina, 2017).

Creative Guidance in Malaysia is one of the alternative mediums for Guidance and Counseling, especially in primary schools. It is through this medium that will be applied in the implementation of the study in dealing with disciplinary issues. Part of the Creative Guidance element is Music. David Adward (2004). According to Cathy. A Malchiodi, (2005), also describes music therapy as part of Creative Therapy, where the effect is very complimentary, especially, in changing behavior, psychology, and ability to socialize. What is interesting here is adapting music therapy as a medium of Guidance. Looking at it psychosocially, it connects my behavior in mixing, in emotions it helps to stabilize emotions, as well as in communication, it helps to build relationships. For the cognitive, as a means of communication, and emotionally, for a sense of security, (David Adward, 2004).

Music therapy is something magical that is widespread, something that is natural, flexible all accustomed to Music, and it is an option. The Music consists of, singing, listening, playing, and movement (Deb Del Signore, Rebecca Froman, Erica Hornthal, 2012). Modules need to be validated to measure the accuracy of a measure used. The validity of the module aims to ensure that the measurements or indicators used to contain all the features or ideas that must be present in the measured concept (Sabitha, 2006). Therefore, the validity of a module refers to the accuracy of the concept and content of a module. According to Rusell (1974), the fact of the module for evaluation is as follows: a) meet the target population, b) the teaching situation or method of implementation of the module is appropriate, c) the time allotted to carry out a process of implementation of the module is sufficient, d) improving student achievement in targeted aspects, and, e) modules successfully change students' attitudes towards more outstanding excellence. Therefore, the validity of the module must contain the above characteristics.

The validity of a measuring instrument refers to the extent to which the tool measures data properly (Paul \& Jeanne, 2005; Anastasi, 1982). Validity is used to measure the accuracy of a measure used in the study. It aims to determine whether the extent or indicator used contains all the features or ideas that should be present in the measured concept (Sabitha, 2006). The validity feature in a measuring device refers to the degree to which it can measure what should be measured (Abd Rashid \& Siti Rahayah, 2001; Md Noor (2012).

According to Sidek \& Jamaludin (2005), a measuring instrument is considered the same meaning as a module. It is because measurement tools and modules are tools, resources, 


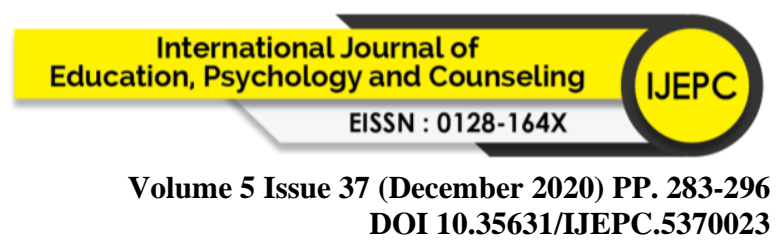

materials that guide a module builder to obtain various information and data related to the study, and research to be done. The validity of a module will describe the extent to which the results should be achieved. It means that the module needs to have objectives that the researcher wants to measure.

In addition to validity, the reliability of a module is determined when the respondent can master the objectives and can also follow the steps for each activity in the module implemented effectively. According to Rusell (1947); Sidek and Jamaludin (2005) and Md Noor (2012), the instrument of evaluating the effectiveness and completeness of the module can be made in two ways, namely, through item questions created based on objectives and both item questions based on the activities stated in each module activity.

Reliability means the consistency of the sample studied. In other words, reliability is a test that has high reliability if the same score is obtained from different individuals (Sidek, 2002). According to Muhammad Aziz Shah (2010), the reliability of a module refers to the consistency and stability of a module in treating what should be treated as in the objective of a module. Therefore, it is clear, according to Rusell (1974), testing the reliability of a module can be seen through the extent to which students can follow the content of a module.

\section{Methodology}

This study uses a descriptive design of a quantitative approach involving content validity analysis and reliability analysis. According to Mohd Majid (2009), descriptive research is suitable to be used to describe the current situation of a phenomenon that is happening, get a perfect explanation, and explore areas that have not been studied to get accurate information. In this study, researchers have used the recommendations of field evaluators (Creswell, 2005; Christensen 2004; Sekaran, 2000; Mohd Majid Kontang, 2009) to determine the validity of the content of the REBT-Creative Guidance Module.

In this study, there are two methods of validity conducted, namely the validity of the face and the validity of the content by external critics (external criticism). Face validity is done to see aspects of module comprehension and language accuracy, while content validity is done through expert verification to view content. Researchers refer to expert panels a total of five people to determine the validity of the REBT-Creative Guidance Theory Module.

Before the evaluation form is given to the expert panel, the researcher has made a complete copy of the REBT-Creative Guidance Module book containing the introduction, general objectives of the module, theoretical basis, overall content, and module attachments provided for review, evaluation, and suggestions for improvement by the panel expert. A set of module content validity instruments based on the views of Rusell (1974), was also given to experts to determine the content level of the REBT-Creative Guidance Module. In the REBT-Creative Guidance Module, the researcher has set.

\section{Study Subjects}

The study subjects to assess facial validity consisted of 5 experts in the field of counselingfour people from 4 local universities. One of them is the REBT module builder, one from the Ministry of Education, one from the secondary school who is also the REBT module builder. A person from the District Education Office is an expert who has served in primary schools. 
And Module Builder. The selection of experts is explicitly seen for primary schools and the field of Specialist education selected to assess the modules and research tools, as in Table 1.

Table 1: List of Module Item Valuation Names Confirmation Billing Profile of Institutions of Expertise

\begin{tabular}{llll}
\hline Bill & \multicolumn{1}{c}{ Names } & Institutions & \multicolumn{1}{c}{ Expertise } \\
\hline 1 & Dr. (University Lecturer) & UTM & Psychology and Counseling \\
& & & REBT Module Develop \\
$\mathbf{2}$ & Dr. (University Lecturer) & UMT & Psychology and Counseling \\
$\mathbf{3}$ & Dr. (Guidance And Counseling) & KPM & Psychology and Counseling \\
$\mathbf{4}$ & Dr. (Secondary School) & SMK & $\begin{array}{l}\text { Psychology and Counseling } \\
\end{array}$ \\
$\mathbf{5}$ & Dr. (Deputy Director) & PPD & REBT Module Develop \\
& & & Psychology and Counseling \\
& & & Module Develop
\end{tabular}

Researchers have prepared a set of evaluation forms for experts to evaluate. There is a scale for evaluation of ten optional points such as; 1 (strongly disagree) to 10 (strongly agree). To determine the validity of the module content, the total score completed by the expert $(\mathrm{x})$ will be divided by the total actual score (y) and multiplied by one hundred. If the total score value is $70 \%$ and above, it indicates that a module has high content validity and is considered to have mastered or achieved a high level of achievement (Tuckman, 1998; Abu Bakar, 1995; Sidek \& Jamaludin, 2005). The formula is as follows.

Number of Experts (x)

Total Actual Score (y)

Meanwhile, to determine the reliability of the REBT-Creative Guidance Module, the researcher has distributed module reliability instruments to 40 students as pilot study respondents (pilot study). The background of the students involved is from students who have disciplinary problems at school. The module reliability instrument is given to the students after they follow each activity in the module. The instrument was analyzed to obtain a reliability value using Cronbach's alpha coefficient method.

\section{Result}

\section{Module Content Validity}

Table 2 shows the Content of the REBT Discipline Enhancement Module Creative Guidance Approach to Irrational Thinking, Aggressive Behavior, and Self-Esteem. This primary school student meets the target population of $82 \%$. Contents of the REBT Discipline Enhancement Module The Creative Guidance Approach to Irrational Thinking, Aggressive Behavior, and Self-esteem of these primary school students can be implemented correctly. 82\%. Contents of the REBT Discipline Enhancement Module Creative Guidance Approach to Irrational Thinking, Aggressive Behavior, and Self-Esteem of these primary school students following the allotted time, 88\%. Contents of the REBT Discipline Enhancement Module Creative 


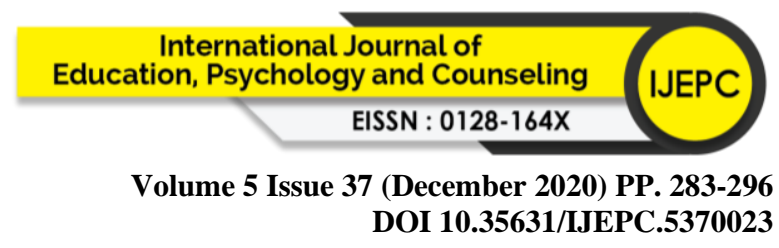

Guidance Approach to Irrational Thinking, Aggressive Behavior, and Self-Esteem This primary school student can increase the level of individual thinking skills more effectively by 84\%. REBT Discipline Enhancement Module Training Content Creative Guidance Approach to Irrational Thinking, Aggressive Behavior, and Self-Esteem This primary school student can change thinking skills to be more excellent $82 \%$.

Overall, the views from the panel of experts indicate that the content of the REBT-Creative Guidance Module is acceptable. It shows that the REBT-Creative Guidance Module has been given a moderate assessment by experts and is suitable for implementation. Findings from expert evaluation based on content validity questionnaire by Rusell (1974), which has been modified by Jamaludin (2002).

Table 2: Validity Value of REBT Module-Creative Guidance Expert Assessment

\begin{tabular}{clcc}
\hline BIL & \multicolumn{1}{c}{ Statements } & View \\
\hline $\mathbf{1}$ Content of the REBT Discipline Enhancement Module & $\mathbf{8 2 \%}$ & Accepted \\
Creative Guidance Approach to Irrational Thinking, \\
Aggressive Behavior, and Self-Esteem This primary \\
school student meets the target population.
\end{tabular}

Table 3. The validity of Sessions and Activities of REBT Guidance Module - Creative Guidance based on expert evaluation. Based on Table 3, shows the total expert score of the suitability of sessions and activities is $89.8 \%$. Activity 1 : I am passionate 1 with a score of $84 \%$. Activity 2: I am passionate, 2 with a score of $82 \%$. Activity 3: Facial expression with a score of $84 \%$.Activity 4: Introduction to the concept of REBT with a score of $86 \%$.Activity 5: I believe, with a score of $80 \%$.Activity 6: my heart with a score of $84 \%$.Activity 7: My Favorite Face 


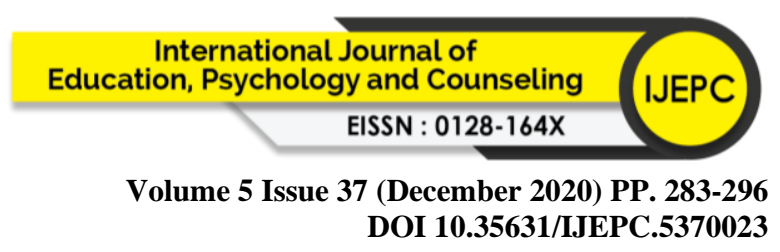

with a score of $84 \%$.Activity $8:$ who am I with a score of $84 \%$.Activity 9: Face Balance with a score of $80 \%$.Activity 10: my real face with a score of $82 \%$.Activity 11 : I am ok with a score of $80 \%$. Activity 12: I Changed with a score of $80 \%$. Activity 13: Survival with a score of $82 \%$.Activity 14: Summary with a score of $86 \%$. The overall findings can be seen based on table 3 below.

Table 3: The Validity of Sessions and Activities of REBT Guidance Module - Creative Guidance Expert Assessment

\begin{tabular}{cccc}
\hline Bil Session & Activity & $\%$ & $\begin{array}{c}\text { Expert } \\
\text { Views }\end{array}$ \\
\hline
\end{tabular}
1. Session 1: Introduction to Activity 1: I am passionate1 $84 \%$ Accepted Building Relationships Activity 2: I am passionate $2 \quad 82 \%$
2. Session 2: Stage A (Activating Activity 3: Facial Expression 84\% Accepted Event) Events / Events + Creative Guidance

3.

Session 3: Stage B (Believe Activity 4: Introduce REBT 86\% Accepted Evolution System) Belief concepts

System + Creative Guidance Activity 5: I believe $\quad 80 \%$

4. Session 4: Stage C Activity 6: my heart is $84 \%$ Accepted

(Consequences) Activity 7: My Favorite Face $84 \%$

Psychological Effects +

Creative Guidance

5. Session 5: Stage D (Dispute)

Activity 8: who am I

$84 \%$ Accepted

Challenging + Creative

Activity 9: Face Balanced

$82 \%$

Guidance (Challenging

Irrational, Aggressive Belief

System and Appreciation

6. Session 6: Stage E (New Activity 10: my real face is $80 \%$ Accepted Effect) (New Belief + Self- Activity 11: I am ok 80\% Accepted Reflection)

7. Session 7: Stage F) New Activity 12: I Changed $82 \%$ Feeling + New Goal

8. Session 8: Termination of Activity 13: Surfing Life 82\% Accepted Activity 14: Summary $86 \%$ 
Table 4: Feedback Findings and Comments for Improvement by Experts

\begin{tabular}{cl}
\hline Expert & \multicolumn{1}{c}{ Comment and Improvements } \\
\hline $\mathbf{1}$ & The contents of the REBT Module need to be deleted in the exercise. Good \\
& activity \\
$\mathbf{2}$ & Needs to be streamlined in writing and modules meet standards. \\
$\mathbf{3}$ & Various activities to hone thinking skills. \\
$\mathbf{4}$ & Implementation should take into account the suitability of the student's cognitive \\
& level \\
$\mathbf{5}$ & Good and follow the Steps in REBT
\end{tabular}

Table 4 shows the comments and suggestions submitted by experts. The researcher has made improvements on the recommendations of the expert panel to achieve the objectives of the study.

\section{Module Reliability}

The reliability determination process of the REBT-Creative Guidance Group Module was carried out on 40 Year 5 students in a selected school. The coaching process was conducted during the eight meetings. After that, the reliability instrument of the REBT-Creative Guidance module is given to the student after following each activity in the module. The instrument was analyzed to obtain a reliability value using Cronbach's alpha coefficient method. Table 5 shows the reliability values based on the sessions and activities of the REBT-Creative Guidance REBT-guidance module.

Table 5: Reliability Values Based on Sessions and Activities of the REBT-Creative Guidance Module

\begin{tabular}{|c|c|c|c|c|}
\hline \multirow[t]{2}{*}{ Bil } & \multirow[t]{2}{*}{ Main Module } & \multirow[t]{2}{*}{ Sub Module } & \multirow{2}{*}{$\begin{array}{l}\text { Value alpha } \\
\text { Cronbach }\end{array}$} & \multirow{2}{*}{$\begin{array}{l}\text { Expert } \\
\text { View }\end{array}$} \\
\hline & & & & \\
\hline $\mathbf{1}$ & $\begin{array}{l}1 \text { Session 1: Introduction to } \\
\text { Building Relationships }\end{array}$ & $\begin{array}{l}\text { Activity } 1: \text { I am passionate } 1 \\
\text { Activity } 2: \text { I am enthusiastic two. }\end{array}$ & .82 & Accepted \\
\hline 2. & $\begin{array}{l}\text { 2. Session 2: Stage A (Activating } \\
\text { Event) Events / Events + Creative } \\
\text { Guidance }\end{array}$ & Activity 3 : Facial Expression & .73 & Accepted \\
\hline 2. & $\begin{array}{l}\text { 3. Session 3: Stage B (Believe } \\
\text { Evolution System) Belief System + } \\
\text { Creative Guidance }\end{array}$ & $\begin{array}{l}\text { Activity 4: Introduction to the } \\
\text { Concept of REBT }\end{array}$ & .76 & Accepted \\
\hline 3. & $\begin{array}{l}\text { 4. Session 4: } \begin{array}{c}\text { Stage } \mathrm{C} \\
\text { (Consequences) }\end{array} \text { Psychological }\end{array}$ & $\begin{array}{l}\text { Activity } 5: \text { I believe, } \\
\text { Activity } 6: \text { my heart. }\end{array}$ & .60 & Accepted \\
\hline & Effects + Creative Guidance & & & \\
\hline 4. & $\begin{array}{l}\text { 4. Session 5: Stage D (Dispute) } \\
\text { Challenging + Creative Guidance } \\
\text { (Challenging } \\
\text { Aggressive Belief System and } \\
\text { Appreciation }\end{array}$ & $\begin{array}{l}\text { Activity } 7: \text { My Eaxorite Face } \\
\text { Activity } 8: \text { who } \operatorname{am} I \text {. }\end{array}$ & .80 & Accepted \\
\hline 5. & $\begin{array}{l}\text { Session 6: Level E (New Effect) } \\
\text { (New Belief + Self-Reflection) }\end{array}$ & $\begin{array}{l}\text { Activity } 9: \text { Face Balanced } \\
\text { Activity } 10: \text { my real face. }\end{array}$ & .88 & Accepted \\
\hline 6. & $\begin{array}{l}\text { Session 7: Stage F) New Feeling } \\
+ \text { New Goal }\end{array}$ & $\begin{array}{l}\text { Activity } 11: \text { I am ok. } \\
\text { Activity } 12: \text { I Changed. }\end{array}$ & .88 & Accepted \\
\hline 7. & Session 8: Termination of & $\begin{array}{l}\text { Activity 13: Surfing Life Activity } \\
\text { 14: Summary. }\end{array}$ & .78 & Accepted \\
\hline
\end{tabular}




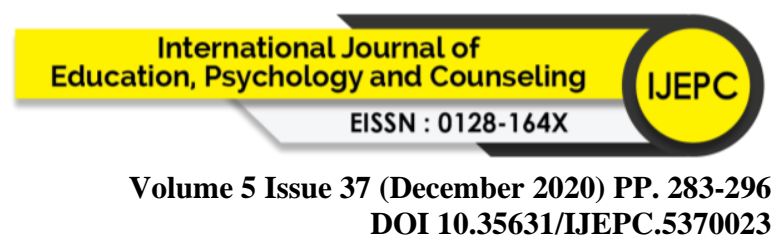

Based on Table 5, the first session shows an alpha value of .82, the second session .73, session third .60 , fourth .80 , fifth session .88 , sixth session .88 , seventh session. 88 and last session .78 . This shows that the overall alpha value for each session is found to be moderate and can be suitable for use in conducting coaching activities. Table 6 shows the pilot study of modules for all sub-sub-modules of REBT-Creative Guidance. The coaching session process took place over eight meeting sessions, including an introductory briefing. Each meeting takes three hours. This session is conducted in the therapeutic room.

Table 6: Module Pilot Study

\begin{tabular}{c|c|c}
\hline Alpha Value & Total item & Number sample \\
\hline .930 & 14 & 40 \\
\hline
\end{tabular}

Based on Table 6 results of all sub-sub-modules REBT Guidance- Creative guidance pilot study involving 40 students as this study with 14 total question items built based on module activities get results that are alpha value

.930 .

\section{Discussion}

Measurement tools and modules are tools, resources, materials that guide researchers in the construction of modules to obtain various information and data related to the study or research to be done, Russell (1974) presented by Sidek \& Jamaludin (2005). Something that a measuring instrument is said to have the same meaning as a module. Module validity means the results achieved to the module. The module should have the objectives that the researcher wants to measure through the evaluation of the evaluator experts who have been appointed. The results of the expert validity for this creative REBT-Guidance Theory Module have gained high validity. This high validity is seen to be able in shaping the system of thinking, behavior, students' self-concept towards a more positive direction. Validity results with $70 \%$ achievement are considered to have mastered or achieved the desired level of achievement, Tuckman (1998) and Abu Bakar Nordin (1995).

Judging from the Analysis, the REBT-Creative Guidance Theory Module reaches more than $80 \%$. It means that this tool can measure all the contents and content of the field studied effectively (Mohd Majid, 1998). Besides, the validity of the content of a measuring instrument also depends on the scope and objectives of the field studied. Where the validity of an instrument, refers to the extent to which an instrument has measured what should be measured. Alias (1992); Creswell (2002, 2005,2010); Pallant (2001); Tuckman (1999).

In terms of reliability, the findings of the study have also shown that the reliability of the REBT Creative Guidance Theory Module as a whole is high, namely .930. If the reliability value obtained is high, at least 0.60 , it means that the module or measuring instrument has the right level of consistency Kerlinger (1979) and Mohd Majid (2000). What is clear if seen based on the findings of validity and reliability that has been made shows the REBT-Creative Guidance Module is acceptable and reliable. This module can also be used in the field of study as a form of intervention in improving rational thinking, reducing aggressive behavior and self-esteem among primary school students 


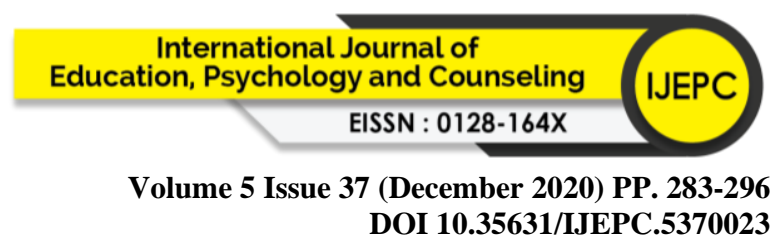

\section{Conclusion}

Overall, it can be concluded that the REBT-Creative Guidance Module is a new form of innovation for guidance and counseling teachers for primary schools in Malaysia. The results of the study conducted by the researcher showed that the REBT-Creative Guidance Module that was built based on the REBT Theory by Albert Ellis (1955) and the Creative Guidance has high validity and reliability. It is also seen as suitable for use in the local context, especially for primary school students aged from 7 years to 12 years. This built-in module can also be used easily by registered guidance and counseling teachers as well as those only appointed by the Ministry of Education Malaysia. Regular teachers or facilitators can also implement it. They are not in the field of counseling as a tool to help in the relationship to help It because it is seen that the operating rules are quickly accompanied by the technology and materials available. In the meantime, this module is also seen as an alternative tool of intervention for high school students as well as students in institutions of higher learning who have irrational thinking, aggressive behavior, and low self-esteem. It is suggested that a more comprehensive study in the form of quasi-expiratory studies should be conducted on children aged 6 to 12 years to see the effectiveness of the creative REBT-Guidance Module Module specifically for guidance and counseling practitioners dealing with child clients.

\section{Reference}

Abdul Malek Abdul Rahman. (2004). Kesan Kaunseling kelompok tingkah laku kognitif dalam merawat tingkah laku lansung buli di kalangan pelajar sekolah menengah. Tesis Dr. Fal. Universiti Kebangsaan Malaysia, Bangi.

Abdul Rashid Johar \& Siti Rahiyah Ariffin (2001). Isu pengukuran dan penilaian pendidikan. Bangi: Fakulti Pendidikan Universiti Kebangsaan Malaysia.

Adcock, S. S., Webster, S. M., Leonard, L. G. \& Walker, J. L. (2008). Benefits of a holistic group counseling model to promote wellness for girls at risk for delinquency: An exploratory study. Journal of Humanistic Counseling, Education \& Development, 47.

Ahmad Jazimin (2008). Penggunaan terapi reality dalam kalangan kaunselor di Malaysia. Tesis DoktorFalsafah yang tidak diterbitkan, Bangi: Universiti Kebangsaan Malaysia.

Ann Vernon And Michael E. Bernard( 2006) Applications of REBT in Schools: Prevention, Promotion, Intervention.

Ann Vernon And Michael E. Bernard( 2006) Applications of REBT in Schools: Prevention, Promotion, Intervention.

Anastasi, A. (1982). Psychological testing. Ed ke-5. New York: Mc Millan Publishing Co. Inc Arzemi Bin Shaari.( 2014). Kesan Kaunseling Individu Terapi Emosi dan Tingkahlaku,( REBT)Kaunseling sedia ada (KSA) dan Kumpulan kawalan ( KK) Terhadap Tingkahlaku Agresif Murid sekolah Menengah.

Azizah Abdullah KB, P. A., Zyzah@uum.edu.my, S. of E., \& Email: M. L. U. U. M. (2018). Creative Arts and Play Therapy Practices in the Helping Profession By.

Aziz, R. A., \& Mohamad, Z. (2015). Terapi Seni Ekspresif Sebagai Intervensi Kaunseling Dalam Memangkinkan Strategi Daya Tindak Ibu Tunggal Rosliza Abd Aziz, (1993).

Azizi Yahaya, \& Rohaya Ahmad. (2010). Faktor-Faktor Penyebab Masalah Disiplin Di Sekolah. ...-Faktor Penyebab Masalah Disiplin Di Sekolah, (1965). Retrieved from http://eprints.utm.my/10404.

Bahagian Pengurusan Sekolah Harian,Kementerian Pendidikan Malaysia,( 2012),Surat Siaran KPM Bil.12 Tahun 2012:Perekayasaan Perkhidmatan Bimbingan Dan Kaunseling di Sekolah . 


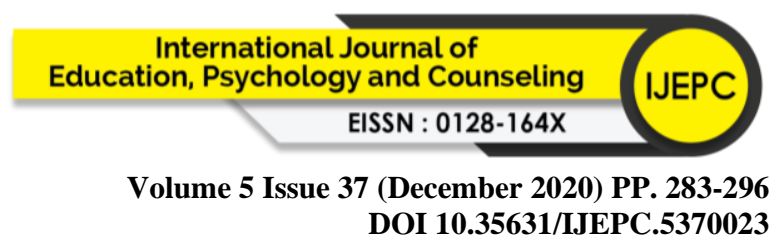

Bahagian Pengurusan Sekolah Harian,Kementerian Pendidikan Malaysia,( 2017), Pengurusan Dan Pematuhan Dasar-dasar,Perkhidmatan Bimbingan Dan Kaunseling,Kementerian Pendidikan Malaysia Di sekolah- sekolah Menegah Dan Rendah.

Bimbing Pelajar Bermasalah Bukan Terus Dibuang-Mohamad Hasan.( 2018,March 14) Utusan Malaysia.

Cathy A.Malchiodi ( 2005), Expressive Therapies, History, Theory, and Practice.

Chang, L.H., Mohd Faris Dziauddin., Baharuddin Jabar., Mohd Noor Daud., Nurul Firdaus Abd Rahman dan Zainuddin Othman. (, 2014). Social science literacy among form four students in Malaysian secondary schools. Journal of Research, Policy \& Practice of Teachers \& Teacher Education, 4(2), 59-72.

Creswell, J. W. (2005). Educational research: Planning conducting and evaluating quantitative and qualitative research. New Jersey: Pearson Education, Inc.

Christensen, L.B. (2004). Experimental methodology (9th ed.). Boston: Pearson Education, Inc. Ellis, A. (1955). Teknik-teknik Konseling Jakarta: PT.Merdika.

Danial David,Aurora Szentagotai, Viorel Lupu,Doina Cosman (2008). Rational emotive behavior therapy, cognitive therapy, and medication in the treatment of major depressive disorder: a randomized clinical trial, posttreatment outcomes, and six-month follow-up

David Edwards ( 2004 ) Creative Therapies in Practise.SAGE Publications.

Deb Del Signore, Rebecca Froman, Erica Hornthal,( 2012 ), Exploring Creative Arts Therapies

Ellis, D. J., \& Ellis, A. (2015). Rational Emotive Behavioural Therapy: The Evolution of a Revolution. Europe's Journal of Psychology, 11(1), 7-15.

Ellis, A., \& Harper, R. A. (1997). A guide to rational living (3rd ed.). Chatsworth, CA: Wilshire.

Ellis, A., \& Dryden, W. (2007). The practice of rational emotive behavior therapy (2nd ed.). New York, NY: Springer Publishing Company.

Ellis, A. (1958). Rational psychotherapy. Journal of General Psychology, 59, 35-49.

Ellis, A., Shaughnessy, M.F., \& Mahan, V. (2003). An interview with Albert Ellis about rational emotive behavior therapy. North American Journal of Psychology, 4(3), 355356.

Grey, E. (2010). Use your brain: A neurologically driven application of REBT with children. Journal of Creativity in Mental Health, 5(1), 54-64.

Gladding, S.T. (2003). Group Work. A counseling specialty. Ed, ke 4. New York: Mc Millan Publication.

Houghton Mifflin. Tuckman, B.W. (1988). Conducting Education Research, $3^{\text {rd }}$ Edition. New York: Harcourt Brace Jovanovich, Inc.

Ibrahim Mohamed Zain (2007). Membina dan mengesahkan instrument pentaksirankecerdasan pelbagai.Tesis Doktor Falsafah yang tidak diterbitkan. Bangi: Universiti Kebangsaan Malaysia.

Ida Hartina Ahmed Tharbe. (2006). Memimpin counseling kelompok. Batu Caves: PTS Professional Sdn Bhd

Izam Shah Basiron. 2007. Perisian permainan pengembaraan multimedia: edutainment dalam pendidikan Agama Islam sekolah rendah. Tesis Sarjana, Fakulti Teknologi dan Sains Maklumat, Universiti Kebangsaan Malaysia.

Kaedah Kaunseling Kurangkan Pelajar Dibuang Sekolah-Mahdhir.( 2017,Okt 23). Astro Awani.MYT.

Kementerian Pendidikan Malaysia.(2014).Modul Pembimbing Rakan Sebaya.

Copyright $\odot$ GLOBAL ACADEMIC EXCELLENCE (M) SDN BHD - All rights reserved 


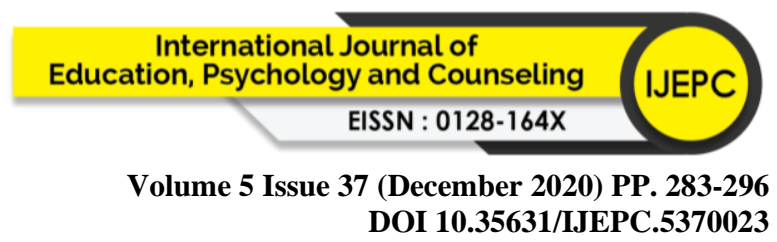

Kementerian Pendidikan Malaysia.( 2012). Surat Siaran Perekayasaan Bimbingan Dan Kaunseling Sepenuh Masa.Bil 12/12.

Kementerian Pendidikan Perlu Kekang Gejala Buli-Lee Lam Thy.( 2018,June 30).Berita Harian.

Jamaluddin Ahmad, Rosdi Yusof \& Saifudin Kumar Abdullah. (2009). The reliability and validity of Tennessee self-concept scale (TSCS) instrument on residents of drug rehabilitation center. Journal of Social Sciences, 10 (3)

Latifah Binti Abdul Majid*; Wan Nasyrudin Wan Abdullah; Nurul Hidayah Binti Ahmad Zakhi ( 2012 ), Penerapan Nilai Murni Dan Pembentukan Jati Diri Kanak-Kanak Prasekolah Melalui Penggunaan Multimedia (Integrating Noble Values And Identity Formation Into Kindergarten Children Through The Use Of Multimedia)Fakulti Pengajian Islam, Universiti Kebangsaan MalaysiaMohd Majid Konting. (1998). Kaedah penyelidikan pendidikan, edisi ke 4. Kuala Lumpur. Dewan bahasa dan Pustaka.

Leedy, P.D., \& Ormrod, J.E. (2005). Practical research: Planning and design (8th ed.) Prentice Hall.

Mohd Majid Konting. (2009). Kaedah penyelidikan pendidikan, edisi ke 8. Kuala Lumpur. Dewan bahasa dan Pustaka.

Neenan, M. (2008). Tackling Procrastination: An REBT Perspective for Coaches. Journal of The Academy of Rehabilitative Audiology No.17 Page 317.

Nico, D., \& Daprati, E. (2009). The egocentric reference for visual exploration and orientation. Brain \& Cognition, 69, 227-235. doi:10.1016/j.bandc.2008.07.011.

Norsayyidatina Binti Che Rozubi ( 2017), Kesan Program Kesejahteraan Psikologi Menggunakan Kaedah Bermain Kepada Kanak- Kanak Sekolah Rendah .Fakulti Pendidikan Universiti Melaya,Kuala Lumpur.

Olivares, R.O., Pino, M. J., \& Herruzo, J. (2010). Reduction of disruptive behaviors using an intervention based on the good behavior game and the say-do report correspondence. Psychology in the School, 47 (10), 1046-1058.

Ponteng Sekolah Catat Rekod Tertinggi Salah Laku Disiplin 2017.( 2018,March 21). Astro Awani.MYT.

Rotan Tindakan Terkkhir Pelajar- Kamalanathan.(2018), Astro Awani.MYT.

Rusell, J. D (1974). Modular instruction: a guide to the design, selection, utilization and evaluation of modular materials. United States: Publishing Company

Rohaya Talib \& Mohd Najib. (2008). Pembinaan dan pengesahan instrument bagi mengukur tahap literasi pentaksiran guru sekolah menengah di Malaysia. (Electronic Version).http://eprints.utm.my

Sabitha Marican. (2006). Penyelidikan sains sosial pendekatan pragmatic. Batu Caves: Penerbit EdusystemSdn Bhd.Sekaran, U. (2000). Research methods for business: A skill building approach. United States of American: John Wiley \& Sons, Inc.

Sidek Mohd Noah \& Jamaludin Ahmad. (2005). Pembinaan modul: Bagaimana membina modul latihan dan modul akademik. Serdang: Penerbit Universiti Putra Malaysia

Shertzer, B., \& Stone, S. C. (1981). Fundamentals of Guidance (4th ed.). Boston, MA:

Sinar Online, (2018). Kesihatan mental: Mantapkan kecekapan, kemahiran kaunselor.

Sinar Harian. http://www.sinarharian.com.my/edisi/perak/kesihatan-mental-mantapkankecekapan-kemahiran-kaunselor-1.866379.

Shamsiah Bt. Mohd. Amin Shahrulbanun Bt. A.Ghani Azaiah Bt . Ab. Latib ( 2005 ). Konsep Dan Pelaksanaan Sekolah Selamat Fakulti Pendidikan Universiti Teknologi Malaysia 
Unit Hal Murid ( 2017 ). Laporan Salah laku Displin Murid Daerah Gombak,Pejabat Pelajaran Daerah Gombak.

Utusan Online, (2018). Bimbing pelajar bermasalah bukan terus buang -Mohamad. Utusan Malaysia.http://www.utusan.com.my/berita/nasional/bimbing-pelajar-bermasalahbukan-terus-buang-mohamad-1.627217.

Wallen, S.R., DiGiuseppe, R., \& Dryden, W. (1992). A practitioner's guide to rational emotive therapy $\left(2^{\text {nd }}\right.$ ed). New York: Oxford University Press. 